\title{
Morphometric Sexual Dimorphism of Frontal Air Sinus: ACT Study
}

\author{
Dr. Pradnyesh N. Panshewdikar ${ }^{1}$, Dr. Gourav D. Thakre², \\ Dr. Deepak S. Joshi ${ }^{3}$, Dr.Baig M.M. Dr.A.G. Deshmukh. ${ }^{5}$ \\ ${ }^{I}$ (Assistant Professor, Department of Anatomy, Dr. V.M. Government Medical College, Solapur, Maharashtra, \\ India) \\ ${ }_{2}^{2}$ (Assistant Professor, Department of Anatomy, Shri Shankaracharya Institute Of Medical Sciences, Junwani, \\ Bhilai, Chattisgrah, India) \\ ${ }^{3}$ (Professor \& Head, Department of Anatomy, Grant Government Medical College, Mumbai, Maharashtra, \\ India) \\ ${ }^{4}$ (Professor\& Head, Department of Anatomy, Government Medical College, Latur, Maharashtra, India) \\ ${ }^{5}$ (Associate Professor, Department of Anatomy,S.R.T.R. Government Medical College, Ambajogai, \\ Maharashtra, India)
}

\begin{abstract}
:
Introduction:The revolutionary changes in the surgical treatment of sinusitis in recent years, particularly in endonasal endoscopic surgery require the clinician to have precise knowledge of nasal sinus anatomy.

Material and Methods:This study was undertaken on head CTs PNS of 119 patients (67 males \& 52 females) in the age group of 12 to 70 years were included in this retrospective study in terms of Antero-posterior diameter, Height, Width \& Volume.

Result:Different parameters in male and female taken on right and left side, the differences among them are not significant.But, values of different parameters in male are towards higher side compared to females. AP diameter, Height \& Volume are towards higher side on right side compared to left; while Width showing opposite i.e. higher values on left side.
\end{abstract}

Conclusions:The sound knowledge of frontal sinus morphometry and variability is very useful to plan surgical approach to frontal sinus and forensic identification of human which applied in medico-legal issues.

Keywords: Frontal Sinus,AP diameter, Height, Width,Volume, Sexual Dimorphism

\section{Introduction}

There exists many historical references to the paranasal sinuses. The earliest such reference can be dated back to the works of Galen, who described the presence of the ethmoid air cells. Later descriptions of the maxillary sinuses by Leonardo da Vinci (1489), the sphenoid sinuses by Giacomo Berengario da Carpi (1521), and the frontal sinuses by Coiter $\left(16^{\text {th }}\right.$ century $)$ introduced early anatomists and scholars to the presence of these craniofacial air cells. ${ }^{[1]}$

The frontal sinus is funnel-shaped cavity, unique to individual and separated by septum. ${ }^{[2]}$

The frontal sinus is often thought as a more "symptomatic sinus" because of the difficulties encountered in frontal sinusitis and maintaining a patent frontal sinus ostium in patients with; difficult to treat frontal rhinosinusitis. ${ }^{[3]}$ The revolutionary changes in the surgical treatment of sinusitis in recent years, particularly in endonasal endoscopic surgery require the clinician to have precise knowledge of nasal sinus anatomy.The aim of this study was to know the morphometric dimensions being useful tool to plan surgical approach to frontal sinus and useful mean of forensic identification of human \& can also be applied in medicolegal issues.

\section{Material \& Methods}

With prior approval of the ethical committee, study was carried out over 119 normal Head CTs PNS (67 males \& 52 females) in the age group of 12 to 70 yrs. with Dual Slice Siemens Volume Access (SOMATOM) CT Scan Machine. So, different Coronal and Axial slices with $0.6 \mathrm{~mm}, 1.25 \mathrm{~mm}$ and $4 \mathrm{~mm}$ thickness were collected and further analysis was done with help of computer analogue attached with CT scan machine.Antero-posterior diameter, Width and Height were taken at their maximum measurements as shown in Figure No. 1\&2. We got Antero-posterior diameter, Width in axial section and Height, Width in coronal section.

If, only axial sections were taken in any patient then,

Height $=\sum$ thickness of all axial sections in which frontal sinus was visible 
And when only coronal sections were taken in any patient then,

Antero-posterior diameter $=\sum$ thickness of all coronal sections in which frontal sinus was visible

Figure No.1: Axial sectionFigure No.2. Coronal section
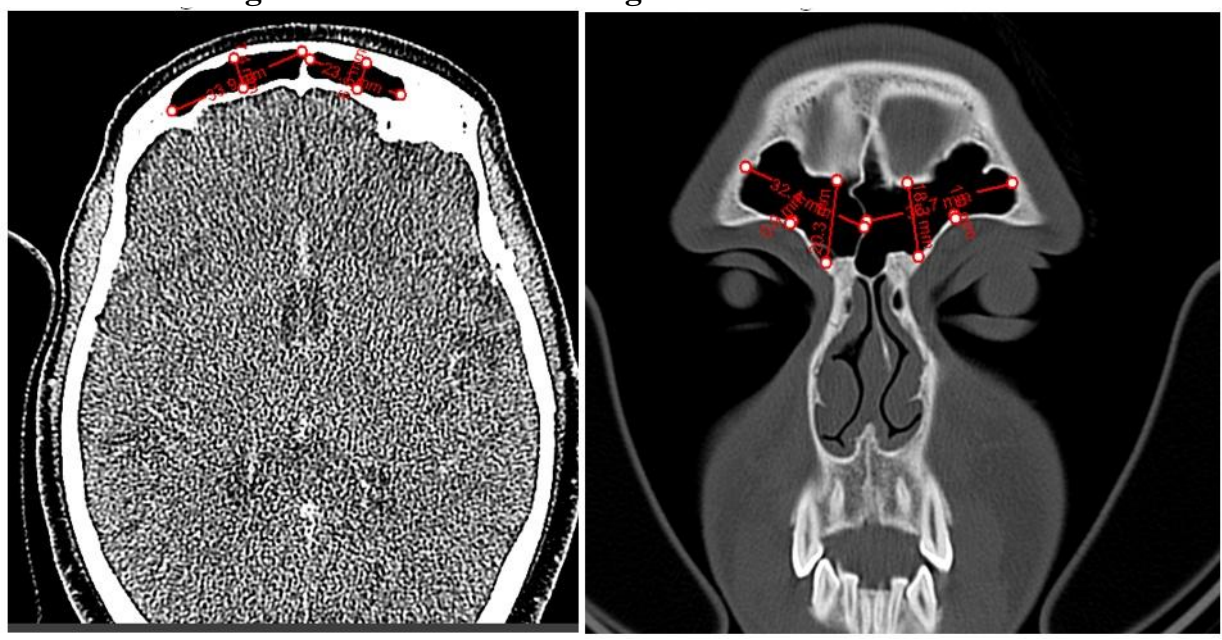

Formula for Volume of Frontal sinus is,

According to Trapezoidal rule by Ikeda A, et al. ${ }^{[4]}$ (1998), Fernandez SJM, et al. ${ }^{[5]}$ (2000)

$\mathbf{V}=[(\mathbf{A} 1+\mathbf{A} 2) \mathbf{h} / \mathbf{2}]+[(\mathbf{A} 2+\mathbf{A} 3) \mathbf{h} / \mathbf{2}]+[(\mathbf{A} 3+\mathbf{A} 4) \mathbf{h} / 2]+$.

Where,

V - Volume of frontal sinus.

A1, A2, A3, A4, .... - Cross-sectional areas of successive CT sections.

h - Thickness of slice.

Figure No.3: Method for calculation of cross-sectional area

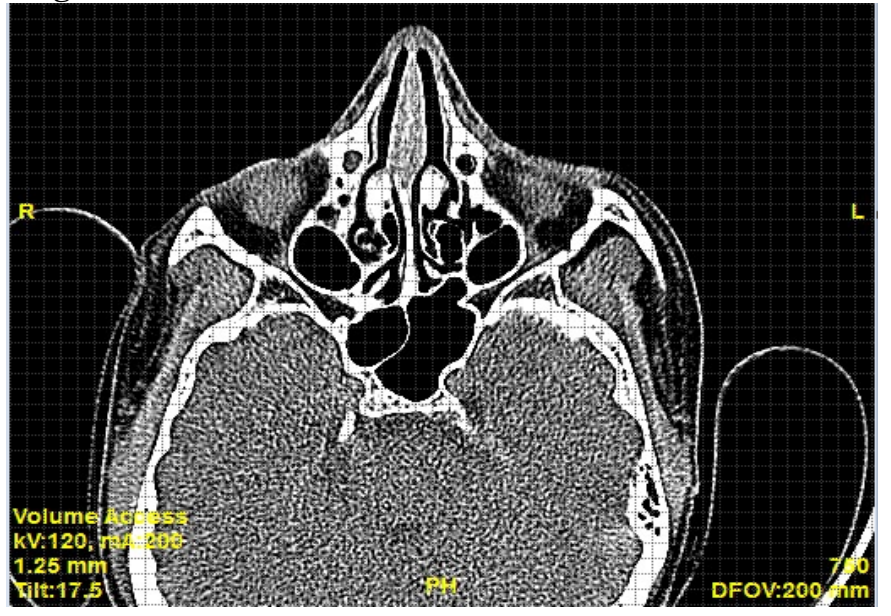

Statistical Analysis

Continuous and categorical variables were presented as (Mean \pm Standard Deviation). A paired t-test was applied and p-value yielded. The statistical analysis was done by using Fisher's Exact Test.

\section{Observations And Results}

The results of the reliability analysis of CT, as a method for the measurement of different dimensions of frontal sinuses are taken gender-wise and side-wise in tabulated form.

\section{1) AP DIAMETER}

Table No. 1: Gender \& Side wise values of AP diameter

\begin{tabular}{|l|c|c|}
\hline Sex & $\begin{array}{c}\text { AP diameter (Right) } \\
(\text { Mean } \pm \text { SD }) \text { in } \mathbf{~ m m}\end{array}$ & $\begin{array}{c}\text { AP diameter (Left) } \\
\text { (Mean } \pm \text { SD) in } \mathbf{~ m m}\end{array}$ \\
\hline Male & $14.38 \pm 6.61$ & $13.9 \pm 6.52$ \\
\hline
\end{tabular}




\begin{tabular}{|l|c|c|}
\hline Female & $12.89 \pm 6.50$ & $12.15 \pm 5.07$ \\
\hline Significance & Not significant & Not significant \\
\hline
\end{tabular}

2) HEIGHT

Table No. 2: Gender \& Side wise values of Height

\begin{tabular}{|l|c|c|}
\hline Sex & $\begin{array}{c}\text { Height (Right) } \\
(\text { Mean } \pm \text { SD) in } \mathbf{~ m m}\end{array}$ & $\begin{array}{c}\text { Height (Left) } \\
\text { (Mean } \pm \text { SD) } \text { in } \mathbf{~ m m}\end{array}$ \\
\hline Male & $15.63 \pm 6.92$ & $15.83 \pm 7.38$ \\
\hline Female & $13.74 \pm 6.18$ & $13.35 \pm 6.85$ \\
\hline Significance & Not significant & Not significant \\
\hline
\end{tabular}

3) WIDTH

Table No. 3: Gender \& Side wise values of Width

\begin{tabular}{|l|c|c|}
\hline Sex & $\begin{array}{c}\text { Width (Right) } \\
\text { (Mean } \pm \text { SD) } \text { in } \mathbf{~ m m}\end{array}$ & $\begin{array}{c}\text { Width (Left) } \\
\text { (Mean } \pm \text { SD) } \text { in } \mathbf{~ m m}\end{array}$ \\
\hline Male & $21.58 \pm 8.76$ & $23.28 \pm 9.88$ \\
\hline Female & $20.54 \pm 9.17$ & $21.34 \pm 9.27$ \\
\hline Significance & Not significant & Not significant \\
\hline
\end{tabular}

4) VOLUME

Table No. 4: Gender \& Side wise values of Volume

\begin{tabular}{|l|c|c|}
\hline Sex & $\begin{array}{c}\text { Volume (Right) } \\
\text { (Mean } \pm \text { SD) } \text { in } \mathbf{~ c m}^{\mathbf{3}}\end{array}$ & $\begin{array}{c}\text { Volume (Left) } \\
\left(\text { Mean } \pm \text { SD) } \text { in } \mathbf{~ c m}^{\mathbf{3}}\right.\end{array}$ \\
\hline Male & $3.21 \pm 1.67$ & $3.06 \pm 1.48$ \\
\hline Female & $3.08 \pm 1.24$ & $2.83 \pm 1.42$ \\
\hline Significance & Not significant & Not significant \\
\hline
\end{tabular}

From Table No. 1,2,3\&4 it is observed that, different parameters in male and female taken on right and left side, the differences among them are not significant.But, values of different parameters in male are towards higher side compared to females. AP diameter, Height \& Volume are towards higher side on right side compared to left; while Width showing opposite i.e. higher values on left side.

\section{Discussion}

Technological advances in this imaging modalities have provided more precise differential diagnosis and greater detail about the anatomic extent of the diseases of PNS. These provide sufficient information for diagnosis and surgical planning in the PNS diseases. ${ }^{[6]}$ There are considerable variations in the shape, capacity and symmetry of the frontal sinuses. The environmental \& genetic factors, ethnicity, craniofacial configuration and the thickness of frontal bone etc. can play a major role in these differences. ${ }^{[7,8,9]}$ In present study parameters such as Antero-posterior diameter, Height, Width, Volume etc. were analysed by applying the multivariate analysis. These various parameters were compared with the earlier studies. Our study, correlates with the study of Tatlisumak E, et al. ${ }^{[10]}\left(\mathbf{2 0 0 8 )} \&\right.$ Mathew KL, et al. ${ }^{[11]}$ (2010) in case of AP diameter, but not in Height \& Width where there is significant male - female difference, that too male having higher values.In the present study, Volume of frontal sinus when compared between male and female, the readings of males are towards higher side as compared to females but, it is not significant. This correlates with Ponde JM, et al. ${ }^{[\mathbf{1 2 ]}}$ (2008). Whereas, Sacide K, et al. ${ }^{[13]}$ (2005) got significant relation; that too more in males as compared to females. This variation could be due to difference in the range of age group.

\section{Conclusion}

Thus sound knowledge of frontal sinus morphometry and variability helps surgeon in carrying out various surgical procedures viz. FESS, cranioplasty and sinus surgery. The morphometric ante-mortem data of particular patient can also be stored for post-mortem identification of the same individual just like record of fingerprint.Finally, we had made an attempt to study mean differences of different sex and side however, no significant difference when compared gender and side wise. But, male and right sided frontal sinuses shows values towards higher side compared to females and left sided frontal sinuses; Except Width, which shows higher values on left side.

* List Of Abbreviations:

- AP Diameter - Antero-Posterior Diameter.

- $\quad$ PNS - Para Nasal Sinuses.

- M-Mean

- $\mathrm{SD}-$ Standard Deviation 


\section{References}

[1]. A John Vartanian. CT Scan of the Paranasal Sinuses [Online].[cited 2012 Oct. 8]; Available from: URL: http://emedicine.medscape.com

[2]. Standring S. Grays Anatomy. 40 ${ }^{\text {th }}$ Ed. England:Churchill livingstone Elsevier Publication; 2008. p.471-72.

[3]. Rubira-Bullen IRF, Rubira CMF, Sarmento VA and Azevedo RA. Frontal sinus size on facial plain radiographs. J. Morphol. Sci. 2010; vol.27 (2), p.77-81.

[4]. Ikeda A,Ikeda M, Komatsuzaki A. A CT study of the course of growth of the maxillary sinus: normal subjects and subjects with chronic sinusitis. ORL J Otorhinolaryngol Relat Spec 1998; vol.60, p.147-52.

[5]. Fernandez SJM, Anta Escuredo JA, SDel SRA, Santaolalla MF: Morphometric study of the paranasal sinuses in normal and pathological conditions. Acta Otolaryngol 2000; vol.120(2), p.273-278.

[6]. Chandan G, et al. Computed tomographic evaluation of diseases of paranasal sinuses 2001; p.1-2.

[7]. Mortimore S, Wornald PJ. Management of acute complicated sinusitis: 5-year review. Otolaryngology and Head and Neck Surgery 1999; vol.121, p.639-42.

[8]. Lund VJ, Lloyd DS, Lloyd G. Imaging for endoscopic sinus surgery in adults JLO 2000; vol.114, p.395-397.

[9]. Prossinger H. Mathematical analysis techniques of frontal sinus morphology, with emphasis on homo. The Anatomical Record 2008; vol.291, p.1455-1478.

[10]. Tatlisumak E, et al. Identification of unknown bodies by using CT images of frontal sinus. Forensic Science International 2007; Vol. $166(1), \mathrm{p} .42-8$.

[11]. Matthew KL, Osama S, Jeffrey HS. CT measurement of the frontal sinus- Gender differences and implications for frontal cranioplasty. Journal of Cranio-Maxillo-Facial Surgery 2010; vol.38, p.494-500.

[12]. Ponde JM, Andrade RN, Via JM, Metzger P, Teles AC. Anatomical variations of the frontal sinus. Int. J.Morphol 2008; vol. 26(4) p.803-808.

[13]. Sacide K, Kavakli A. Morphometric examination of paranasal sinuses and mastoid air cells using computed tomography. Ann Saudi Med. 2005; vol. 25(1), p.41-45. 